\title{
Business Licensing Policy of Tourism Services Concerning Lampung Province Coastal Area's Protection
}

\author{
Muhamad Syaiful Dahlan \\ syaifuldahlan22@gmail.com \\ Institute Teknologi Sumatera, Indonesia
}

Submitted: 28 January 2021; Reviewed: 22 February 2021; Accepted: 02 March 2021

\begin{tabular}{ll}
\hline \multicolumn{1}{c}{ Article's Information } & Abstract \\
\hline Keywords: Business; Licensing; & Implications of licensing for the protection of \\
Policy; Coastal. & coastal areas in the implementation of business \\
DOI: & licensing for tourism services in Lampung \\
https://doi.org/10.25041/aelr.v2i1.2252 & Province following the Lampung Governor \\
& Regulation No. $21 / 2019$ have implications for \\
& protecting coastal areas around tourist objects \\
& marine tourism permit requirements must \\
& include Environmental Documents and \\
& Environmental Permits. Also, it includes a \\
& technical feasibility research document \\
& containing the coordinates of the location of \\
& use, plans for marine tourism activities, and a \\
& list of the infrastructure used. This research \\
& aims to analyze the tourism service business \\
& licensing policy in Lampung Province \\
& concerning the protection of coastal areas. \\
& This research used an empirical juridical \\
approach, and data collection was carried out \\
by literature research and field studies. The \\
data analysis was done qualitatively. The \\
results of this research indicate that the \\
tourism service business licensing policy to the \\
protection of coastal areas in Lampung \\
Province is implemented by the Lampung \\
Province Office of Capital Investment and One \\
Entry Services of Lampung Province based on \\
the Lampung Governor Regulation No. \\
21/2019 concerning Spatial Utilization of \\
\hline \hline
\end{tabular}


Coastal Areas and Small Islands. Licensing for tourism services business with marine tourism objects includes permits for coastal waters locations and water locations. The validity period of the coastal waters management permit and the permit for the waters' location is two years, and a permit extension can be made no later than three months before the permit's validity period.

\section{A. Introduction}

Tourism potential is a tourist attraction for regions to increase local revenue and create community welfare in tourism. ${ }^{1}$ One of the potential tourism resources in Indonesia today is marine tourism. ${ }^{2}$ Business prospects of tourism services, especially marine tourism, are business activities that must obtain a permit. This is because marine tourism objects are related to coastal areas whose existence must be protected not to disturb their sustainability. Licensing is one of the state administrative law instruments that has a function as law in general. Law that can direct and accommodate legal needs as well as public awareness of the law. ${ }^{3}$

Licensing law is a legal instrument or statutory regulation to grant permits for community activities or businesses that continue to develop in the current modernization era. ${ }^{4}$ Legislation, in this case, is static while society is dynamic. Implementers of law or statutory regulations must be professional in synergizing society's rules and conditions so that they can produce a just, useful, and legal certainty in society. ${ }^{5}$ The purpose of licensing is to regulate various actions that legislators do not all deem reprehensible but are expected to carry out moderate supervision.

Lampung Province has abundant marine tourism, especially in the coastal area of Lampung Bay, which is located on the south coast, which can become a leading tourist destination in Lampung. In the last three years, the condition of tourist visits in Lampung Province reached 3.3 million to reach domestic tourists. Apart from tourism, Lampung also has abundant natural resource management. To regulate, develop, supervise, and control tourism operations throughout the Lampung Province, the government has made a licensing policy to protect coastal areas from marine business activities. The needs and problems that exist in society change. For that reason, the government will be faced with the conditions of the community, which are always changing and demands for excellent service, but the capabilities of the government are limited.

Licensing issues for marine tourism, especially in coastal areas, are certainly a problem for the Lampung Provincial government; one of the problems that often arise is beach tourism's opening without prior permission from the government. Lampung Province has tourism objects and beauty, both cultural arts and extraordinary natural potential scattered in

\footnotetext{
1 Jelly N. Sendow, "PERLINDUNGAN HUKUM TERHADAP KEGIATAN PENANAMAN MODAL PADA SEKTOR PARIWISATA DI KABUPATEN MINAHASA UTARA,” LEX ADMINISTRATUM, vol. 3, November 5, 2015, https://ejournal.unsrat.ac.id/index.php/administratum/article/view/9998.

2 Marcella Apriani Lawang, "PENEGAKAN HUKUM TERHADAP PENCEMARAN DAN PERUSAKAN LINGKUNGAN OBJEK WISATA BERDASARKAN UNDANG-UNDANG NOMOR 10 TAHUN 2009," LEX CRIMEN, vol. 4, November 8, 2015, http://analisispengembanganpariwisata.blogspot.com/.

${ }^{3}$ Andrian Sutedi, Hukum Perizinan dalam Sektor Pelayanan Publik, Sinar Grafika, Jakarta, 2017, pg. 192.

4 Dion Hardika Sumarto. Tinjauan Hukum Terhadap Pelayanan Pembenahan Perizinan di Provinsi DKI Jakarta. http://lib.ui.ac.id/file?file=digital/20232850-T28905-Tinjauan\%20hukum.pdf

${ }^{5}$ Primastuti Sari Anggraeini. "Penegakan Hukum Administrasi terhadap Pelanggaran Ketentuan Izin Mendirikan Bangunan Untuk Kegiatan Usaha di Kabupaten Klaten". http://e-journal.uajy.ac.id/12128/1/JURNAL\%20HK11149.pdf.
} 
districts/cities throughout Lampung Province. These attractions and beauty attract tourists to visit Lampung Province. ${ }^{6}$ For this reason, the number of tourists visiting Lampung Province from year to year continues to increase. This is following the following data:

\begin{tabular}{|c|c|c|c|}
\hline \multirow{2}{*}{ Year } & \multicolumn{2}{|c|}{ Tourists } & \multirow{2}{*}{$\begin{array}{c}\text { Total of } \\
\text { Tourists }\end{array}$} \\
\cline { 2 - 3 } & Domestic & Abroad & 2.639 .370 \\
\hline 2014 & 2.581 .165 & 58.205 & 3.467 .715 \\
\hline 2015 & 3.392 .125 & 75.590 & 4.422 .716 \\
\hline 2016 & 4.327 .188 & 95.528 & 5.645 .710 \\
\hline 2017 & 5.530 .803 & 114.907 & 7.085 .251 \\
\hline 2018 & 6.697 .624 & 387.627 & \\
\hline
\end{tabular}

Data from 2014 to 2018 shows that domestic and foreign tourists' number visits to Lampung Province have increased. This is certainly very encouraging because, in addition to contributing income to the region, it can also have a positive impact on the Regional Original Income or Pendapatan Asli Daerah (PAD) of Lampung Province.

Other types of PAD sources are as follows:

a. The results of regional taxes are local levies following regulations stipulated as public legal materials in the framework of financing their households.

b. The result of local fees is payments to the state made to those who use state services.

c. The results of regional owned companies and the results of regional wealth management. Regional companies are production units that provide services, carry out public use and generate income.

d. Regional companies are engaged in activities under their household affairs according to the laws governing the regional government's principles. ${ }^{7}$

Some of the problems faced are related to marine tourism and coastal area management, namely the problem of damage to the physical environment of the coast, the occurrence of social/horizontal conflicts between managers and communities in the coastal environment, and the absence of legal uncertainty over authority, ownership, and control over coastal area resources. ${ }^{8}$ Potential conflicts over the use of coastal areas as marine tourism objects are certainly against the idea that humans should live harmoniously side by side and are interdependent with one another. However, there can be friction in social life that leads to horizontal conflicts. ${ }^{9}$ In this context, the state plays a role in organizing a good national and state life, so that mechanisms are needed to ensure the interests of the majority of society or citizens, ensuring legal certainty so that various criminal behavior and arbitrary actions by community members against other members of society can be avoided. ${ }^{10}$

\footnotetext{
${ }^{6}$ https://lampungprov.go.id/index.php\# accessed on 29 October 2019.

7 Yuswanto, Nurmayani, Ati Yuniati, Marlia Eka Putri, Eka Deviani dan Satria Prayoga. Hukum Keuangan Negara. Fakultas Hukum Universitas Lampung. 2014. pg. 133-134

${ }^{8}$ Bengen, D.G.,\& Retraubun, A.S.W. "Menguak Realitas dan Urgensi Pengelolaan Berbasis Eko-Sosio Sistem Pulau-Pulau Kecil”. Bogor. (ID): Pusat Pembelajaran dan Pengembangan Pesisir dan Laut. Institut Pertanian Bogor.

${ }^{9}$ Muhammad Fadli Nurdin. 2013. "Pengaruh Kegiatan Wisata Bahari Terhadap Tingkat Kesejahteraan Masyarakat Pesisir (Studi Kasus di Pantai Patra Sambolo Kecamatan Anyer Kabupaten Serang)" http://pustaka.unpad.ac.id/wpcontent/uploads/2015/04/8.

${ }^{10}$ Budhiawan, G.P., Indarjo, A.,\& Suryono. "Kajian Kesesuaian dan Daya Dukung Wilayah Pesisir Pantai Bandengan Jepara sebagai Upaya Optimalisasi Pengembangan Kegiatan Wisata Bahari”. Journal of Marine Research, 2 (4), 2013.
} 
The coastal area management as a tourist attraction must pay attention to the balance of nature and its preservation. The utilization of coastal areas must be long-term oriented and not only for business purposes but also for environmentally sound. ${ }^{11}$ The coastal area is a strategic area whose existence must be protected and utilized maximally for the community's benefit. Therefore, licensing in the field of management and utilization of coastal areas is the government's focus, both at the central and regional levels. ${ }^{12}$ Because licensing facilities for the community are also an effort to protect the government against community activities. Based on the explanation above, this research's problem is how the tourism service business is licensing policy in Lampung Province concerning the protection of coastal areas. This research uses an empirical juridical approach, which means that legal research is about enacting or implementing normative legal provisions in action at any particular legal event that occurs in society with primary and secondary data obtained through interviews and literature study. Data analysis was carried out by qualitative analysis to obtain research conclusions.

\section{B. Discussion}

Permission or licensing is a statement or decision applied to an act or action originally prohibited. However, if the act is carried out, it is not detrimental and can still be implemented with strict control and a well-executed state administration system. ${ }^{13}$ Environmental management licensing laws are formed and created to protect and protect humans and the environment from becoming victims of procedural errors in using something or human activity or business. ${ }^{14}$ Licensing law was created to achieve legal order and certainty. Legal rules have an important and significant role in regulating human behavior to create order in people's lives to be created and legal certainty for the entire community without exception. ${ }^{15}$ The agency authorized to carry out-licensing in an integrated manner in Lampung Province is the Office of Capital Investment and One Entry Services of Lampung Province. Likewise, with a license in the tourism service business sector, business actors must apply for a license following the applicable laws and regulations. The tourism service business activities carried out have business legality and legal certainty in carrying out and developing their business. Marine tourism a Marine tourism licensing is the direction of a certain series of actions for tourism service businesses utilizing coastal areas. Licensing has two essential characteristics: it is prepared before a certain series of actions is carried out and is consciously developed with a specific purpose. ${ }^{16}$

\footnotetext{
${ }^{11}$ Ilham Marasabessy et al., "Strategi Pengelolaan Berkelanjutan Pesisir Dan Laut Pulau Nusa Manu Dan Pulau Nusa Leun Di Kabupaten Maluku Tengah Sustainable Coastal and Marine Management Strategies of Nusa Manu and Nusa Leun Islands in Central Maluku Regency," Journal of Regional and Rural Development Planning Februari 2018, no. 1: 1-22, accessed January 28, 2021, https://doi.org/10.29244/jp2wd.2018.2.1.1-22.

12 Martha Hadi Natha, Ambo Tuwo, and Farid Samawi, "KESESUAIAN EKOWISATA SELAM DAN SNORKLING DI PULAU NUSA RA DAN NUSA DEKET BERDASARKAN POTENSI BIOFISIK PERAIRAN Suitability Ecotourism Diving and Snorkeling in Nusa Ra and Nusa Deket Island Based Biophysical Potential Water," J. Sains \& Teknologi, Desember 14, no. 3 (2014): 259-68.

${ }^{13}$ Spelth. N.M. dan Ten Berge. Pengantar Hukum Perizinan, ABJM. Jakarta, 2006, pg.27.

${ }^{14}$ Studi Kasus Wisata Bahari di Pulau Maratua et al., "The Water Location Permit as the Non-Tax State Revenue (NTSR): Case Study on Marine Tourism in Maratua Island," Buletin Ilmiah Marina Sosial Ekonomi Kelautan Dan Perikanan 6, no. 1 (June 30, 2020): 37-49, https://doi.org/10.15578/marina.v6i1.8886.

${ }^{15}$ Bayi Priyono, "Perizinan Sebagai Sarana Pengendalian Penataan Ruang Dalam Perspektif Pemanfaatan Ruang Di Daerah ," Jurnal Ilmiah Administrasi Pemerintahan Daerah, accessed January 28, 2021, http://ejournal.ipdn.ac.id/JAPD/article/view/187.

${ }^{16}$ Diah Yustinaningrum, "PENGEMBANGAN WISATA BAHARI DI TAMAN WISATA PERAIRAN PULAU PIEH DAN LAUT SEKITARNYA MARINE TOURISM DEVELOPMENT IN PARK TOURISM ISLANDS OF PIEH AND SEA SURROUNDING," Agrika, vol. 11, May 1, 2017, https://doi.org/10.31328/JA.V1111.455.
} 
Permits are one of the most widely used instruments in administrative law. The government uses permits as a juridical means to control citizens' behavior. An environmental permit is a public legal instrument in the form of direct regulation in environmental law. The implementation of tourism service businesses must meet environmental permits following Law No. 32 of 2009 concerning Protection and Management of the Environment. The permit requirements include Environmental Impact Analysis or Analisis Dampak Lingkungan (Amdal), or Environmental Management Efforts or Upaya Pengelolaan Lingkungan Hidup (UKL), and Environmental Monitoring Efforts or Upaya Pemantauan Lingkungan Hidup (UPL). This is following Article 2 Paragraph (1) of Government Regulation No. 27 of 2012 concerning Environmental Permits regulates that every business and/or activity that is obliged to have an AMDAL and UKL-UPL must have an environmental permit. This needs to be given so that the implementation of various tourism businesses can complement each other, are interrelated, and mutually support one another.

The regulation regarding licensing is an effort to reform the law by the government to aim that the values and legal norms follow the characteristics and personality of the Indonesian people. The renewal of the law's substance is carried out with the intention that the Indonesian nation has a legal system that reflects the values of national life that have high cultural or socio-cultural roots as a legacy of the ancestors of the Indonesian nation. ${ }^{17}$ The values in the life of the Indonesian nation are as stated in the Pancasila. Suppose these values are not practiced in everyday life because its human resources' quality very much determines a nation's success in achieving its goals. Pancasila values as the nation's philosophy of life need to be implemented to awaken the nation's character, decreasing. Pancasila is a critical and rational image as the basis of the state and the cultural reality of the nation to obtain the main points of understanding fundamentally and comprehensively.

The Indonesian nation has made Pancasila the basis of the state and a view of life in the life of the nation and state. The model of law enforcement should be humanistic. Humanistic criminal law enforcement can be realized by forming laws containing the religious values of Pancasila, humanity, and social issues, and reflects the value of justice, the value of use, and the value of legal certainty. ${ }^{18}$ The whole series of activities to organize/maintain the balance of rights and obligations of citizens under human dignity and accountability according to their functions fairly and equitably, with laws and regulations of law and legislation which are the embodiment of Pancasila and the 1945 Constitution. ${ }^{19}$

The strategy to improve the community's economy through ecotourism areas is manifested in the form of training, school infrastructure development, sea turtle conservation, and strategies for promotion or marketing. The output of these training activities is the development of collective awareness in building collective business and marketing and protecting the coastal environment. ${ }^{20}$ Observations in the field show that several areas that become tourist attractions are beaches, mangroves, lowland tropical rain forests, lake and cave ecosystems. Seeing the tourism potentials in Indonesia, the government should be more selective in granting permits for existing ecotourism, especially in Lampung Province. The

\footnotetext{
${ }^{17}$ Muladi, Demokrasi, Hak Asasi Manusia dan Reformasi Hukum di Indonesia, The Habibie Center, 2002, Jakarta, pg. 34. ${ }^{18}$ Sopian Sitepu dan Nenny Dwi Ariani Maroni, "Humanistic Law Enforcement as the Application of the Value of Justice, Expediency and Legal Certainty Based on Pancasila ," Journal of Legal, Ethical and Regulatory , accessed January 28, 2021, https://www.abacademies.org/abstract/humanistic-law-enforcement-as-the-application-of-the-value-of-justice-expediencyand-legal-certainty-based-on-pancasila-8551.html.

${ }^{19}$ Heni Siswanto. Rekonstruksi Sistem Penegakan Hukum Pidana Menghadapi Kejahatan Perdagangan Orang. Penerbit Pusataka Magister, Semarang, 2013.pg.77.

${ }^{20}$ Yuni Ratna Sari and Dian Kagungan, "KEBIJAKAN PENGEMBANGAN KAWASAN WISATA BAHARI BERBASIS KEARIFAN LOKAL DAN PENGUATAN KELEMBAGAAN DESA DALAM RANGKA MENINGKATKAN KESEJAHTERAAN MASYARAKAT," Econosains Jurnal Online Ekonomi Dan Pendidikan 14, no. 1 (March 31, 2016): 88-104, https://doi.org/10.21009/econosains.0141.07.
} 
policy pursued by the Lampung Provincial Government regarding the licensing of a tourism services business with marine tourism objects is to enforce the Lampung Governor Regulation No. 21/2019 concerning Spatial Utilization of Coastal Areas and Small Islands. According to Article 1 Number 23 of this Governor Regulation, what is meant by marine tourism is the activity of utilizing coastal waters and waters of small islands for tourism purposes.

According to Nirwan Yustian ${ }^{21}$ The policy pursued by the Lampung Provincial Government by enacting the Governor of Lampung Regulation Number 21 of 2019 concerning the Utilization of Space in Coastal Areas and Small Islands is a strategic step. It serves as a legal umbrella in implementing licensing for coastal areas, both for tourism and other interests. In connection with this matter, every person or legal entity carrying out spatial use of part of the coastal waters and waters around small islands permanently must have a Coastal Water Location Permit. Furthermore, the Coastal Water Location Permit becomes the basis for granting a Coastal Water Management Permit, both for marine tourism and other interests. The improvement of this tourism service business is by remembering that the management of various natural resource potentials as tourism objects is one source of PAD that can support regional development optimally. Tourism development does prioritize not only economic development but also culture.

Licensing of a tourism services business with marine tourism objects following Article 3 of the Lampung Governor Regulation No. 21/2019 includes permits for coastal water locations and coastal waters management permits. Furthermore, in Article 4, it is stated that the permit for the location of coastal waters is given based on the 2018-2038 Coastal Areas and Small Islands Zoning Plans for the Province of Lampung. The permit for the location includes a Public Use Area and a Conservation Area. Licensing for tourism services business with suitable marine tourism objects includes permits for coastal waters locations and coastal waters management permits. Business actors have the right to obtain services and guidance from the regional government to continue their business, carry out their business activities following the permits they have, and get protection from the local government for the continuity of their business according to the permits they have. ${ }^{22}$ Licensing for coastal areas reflects administrative order to guarantee legal certainty in the land sector, including the issuance of proofs and maintenance. ${ }^{23}$

The tourism sector is one of the regional financial supports, so it must be developed to increase regional revenue. If the local government and the private sector can synergize well in developing tourist objects' potential, the greater the benefits will be for regional revenues. ${ }^{24} \mathrm{In}$ this era of regional autonomy, local governments must optimize regional revenues to finance the implementation of development and public services. The tourism sector is significant in increasing regional revenues. The more tourist arrivals, both foreign and foreign, the greater regional revenues and revenues. ${ }^{25}$ Economic development is carried out with balanced growth. The tourism sector can also play a decisive role and act as a catalyst to gradually increase the

\footnotetext{
${ }^{21}$ Results of interviews with Nirwan Yustian as Head of the Office of Capital Investment and One Entry Services of Lampung Province. 17 September 2020.

22 Josef Alfonsius and Gadi Djou, "PENGEMBANGAN 24 DESTINASI WISATA BAHARI KABUPATEN ENDE," Jurnal Kawistara 3, no. 1 (April 21, 2013), https://doi.org/10.22146/kawistara.3958.

${ }^{23}$ F.X. Sumarja. Hukum Tata Guna Tanah di Indonesia. Penerbit Universitas Lampung Bandar Lampung. 2008. pg.61.

${ }^{24}$ Armida S. Pengembangan Pariwisata Daerah Memasuki Era Otonomi Daerah dan Desentralisasi. Universitas Indonesia. Jakarta. 2006. pg. 44

${ }^{25}$ Sri Nurhayati Qodriyatun, "Implementasi Kebijakan Pengembangan Pariwisata Berkelanjutan Di Karimunjawa," Aspirasi: Jurnal Masalah-Masalah Sosial 9, no. 2 (March 26, 2019): 240-59, https://doi.org/10.46807/aspirasi.v9i2.1110.
} 
development of other sectors. ${ }^{26}$ The advancement of the tourism industry is highly dependent on the number of tourists who come and the existence of balanced economic growth. ${ }^{27}$

The extent of the coastal area in Lampung Province is regulated in Article 5 of the Lampung Governor Regulation No. 21/2019 explains that tourism service businesses must fulfill permits for locations in coastal waters in public use areas and permits for locations for coastal waters in conservation areas. The procedure for granting a permit for the location of coastal waters is regulated in Article 10 of the Lampung Governor Regulation No. 21/2019 means that every person and cooperative to have a permit for the location of coastal waters following Article 5 must apply to the Governor through the Head of Service, both online and offline. The application for a license must meet administrative and technical requirements.

Article 11 Governor Regulation of Lampung Province No. 21/2019 arrange:

(1) Administrative requirements as intended in Article 10 paragraph (2) letter a, for individuals include

a. Photocopy of the applicant's proof of identity in the form of a valid ID Card/Kartu Tanda Penduduk (KTP), or Driver's License/Surat Izin Mengemudi (SIM), or passport

b. Photocopy of Taxpayer Identification Number or Nomor Pokok Wajib Pajak (NPWP)

c. A written statement of the correctness of documents with sufficient duty stamp

(2) Administrative requirements, as referred to in Article 10 paragraph (2) letter a, for corporations include

a. Company's Profile

b. Photocopy of company establishment deed and their amendments;

c. Photocopy of proof of identity (KTP) of the person in charge of the company;

d. Photocopy of the company's NPWP;

e. Share ownership composition;

f. The composition of the management and line of business of the company

g. Domicile of business;

h. Photocopy of capital investment principle's license

i. A written statement of the correctness of documents with a sufficient duty stamp.

(3) Administrative requirements, as referred to in Article 10 paragraph (2) letter a, for cooperatives include

a. Cooperative's Profile;

b. Photocopy of cooperative establishment deed and their amendments;

c. Photocopy of proof of identity (KTP) of the person in charge of the cooperative;

d. Photocopy of the Cooperative's NPWP:

e. Photocopy of Articles of Association/Bylaws

f. Photocopy of capital investment principle's license:

g. Photocopy of Investment License:

h. A written statement of the correctness of documents with sufficient stamps.

Enforcement of tourism area licensing legal instruments, in this case, is a means of enabling the achievement of objectives. This dimension includes the systems and basic principles of organizing the practice of state administration and social institutions. This plays a role in determining the regulation of people's behavior in dealing with various basic problems. This facility's dimensions contain a legal order and institutions that must follow the

\footnotetext{
${ }^{26}$ Nyoman Pendit. Ilmu Pariwisata Sebuang Pengantar Perdana, Pradnya Paramita, Jakarta. 1994. pg.12.

27 Ferncius Limbong et al., "DAMPAK PERKEMBANGAN PARIWISATA TERHADAP LINGKUNGAN TAMAN NASIONAL KARIMUNJAWA," $\quad$ Ruang, $\quad$ vol. $2, \quad$ December $24, \quad 2014$, https://ejournal3.undip.ac.id/index.php/ruang/article/view/4368.
} 
principle of solidarity, a social structure in a political order according to the principle of justice for society. ${ }^{28}$ Tourism areas must be developed with a good strategy to be sustainable and passed on to the next generation. The government, in this case, plays an important role in enforcing regulations in the field of tourism permits. ${ }^{29}$ Management of small island resources in marine tourism must pay attention to the principle of ecological balance. The use of natural resources by humans must be sagacious and consider environmental sustainability. ${ }^{30}$ Tourism development in small islands must also actively involve and empower the community and local wisdom in the region. ${ }^{31}$

According to Heri Budi Santoso ${ }^{32}$ The main marine tourism is a tourism activity that prioritizes coastal resources and coastal community culture as recreation, sports, and enjoying the scenery. Also, marine tourism is a tourism activity that prioritizes underwater resources and seawater dynamics such as diving, snorkeling, surfing, jet-skiing, glass boats, and animal tourism. Marine tourism is a form of tourism that is managed with a conservation approach. Thus, marine tourism is very appropriate and effective in maintaining ecosystems' integrity and authenticity in unspoiled areas. Article 12 Governor Regulation of Lampung Province No. 21/2019 explains that the Technical Requirements for Permits for the location of coastal waters for permits granted to each person and cooperatives are as follows:

a. Location plan or a map with geographic coordinates in the form of space and/or polygons, at least 4 points of latitude, and longitude coordinates with a scale of at least 1: 5000. by stating the area requested

b. Statement of non-objection from other marine space users who have been around the petitioned location with a sufficient stamp;

c. Activity proposal consisting: introduction, background, legal basis, and geographic location

d. Environmental description, including existing utilization; coastal and oceanographic ecosystems; carrying capacity and carrying capacity: the socio-economic conditions of the community around the location and the conditions of the facilities/infrastructure around the location

e. Plan of activities, including area and geographic location of location: alignment with the Zoning Plan for Coastal Areas and Small Islands of Lampung Province; technical description of space utilization; and a business plan for economic and financial aspects business analysis and efficiency.

Furthermore, in terms of the procedure for granting a Coastal Water Location permit, it is regulated in Article 14 of the Lampung Governor Regulation No. 21/2019:

(1) An applicant for a license applies to the Governor through the Head of Service, who is equipped with the requirements as determined.

(2) The agency shall check the completeness of the application requirements.

(3) The application shall be submitted by the technical OPD service no later than 2 (two) days for a technical study to be carried out, which includes technical requirements and a field survey.

(4) The results of the field survey are contained in the Official Report of the Field Survey.

\footnotetext{
28 Noor Nailie Azzat. "Analisis Perencanaan Pengembangan Kawasan Pariwisata Karimunjawa yang Berkelanjutan (Sustainability Tourism) Kecamatan Karimunjawa, Kabupaten Jepara”. https://dspace.uii.ac.id/bitstream/handle/

${ }^{29}$ SADAR PAKARTI BUDI, "MODEL STRATEGI PENGEMBANGAN KAWASAN PARIWISATA YANG BERDAYA SAING DAN BERKELANJUTAN : DKI JAKARTA,” 2016.

${ }^{30}$ Yar Johan, "Pengembangan Wisata Bahari Dalam Pengelolaan Sumberdaya Pulau-Pulau Kecil Berbasis Ekologi: Studi Kasus Pulau Sebesi Provinsi Lampung," Jurnal Pascasarjana Institut Pertanian Bogor, 2011, http://repository.ipb.ac.id/handle/123456789/50748.

31 Prima Farid Budianto et al., "IMPLEMENTASI PENGEMBANGAN PARIWISATA DI PULAU-PULAU KECIL TERHADAP MASYARAKAT PESISIR DESA LIHUNU, KECAMATAN LIKUPANG, KABUPATEN MINAHASA UTARA, PROVINSI SULAWESI UTARA," Jurnal ECSOFiM, vol. 1, October 28, 2013, https://ecsofim.ub.ac.id/index.php/ecsofim/article/view/5.

32 The interviews with Heri Budi Santoso as Head of the Planning Subdivision of the Tourism and Creative Economic Office of Lampung Province. 15 September 2020.
} 
Tourism service business licensing about the protection of coastal areas, in this case, has a goal dimension formulated to achieve community welfare and live peacefully based on freedom and justice. In a democratic country, the government is fully responsible for these two commitments by implementing good public policies. In dealing with governance problems, the government's general policy must be formulated in its priorities, programs, methods, and philosophical basis and be transparent about what to be held accountable for. Based on this general policy, people's representatives and community groups can evaluate the government's implementation and performance and demand public accountability and accountability. The implementation of licenses for tourism service businesses, especially marine tourism, must comply with the guidelines/criteria/standards that are determined. Another thing that is no less important is organized supervision which contains procedures for the implementation of supervision, who carries out supervision, and what matters are supervised. In carrying out supervision, personnel carrying out the supervisory function can carry out supervision properly and effectively under the existing provisions.

\section{Conclusion}

Based on the results of research and wetting, the conclusion in this study is that the licensing of tourism services business about the protection of coastal areas in Lampung Province is carried out by the Office of Capital Investment and One Entry Services of Lampung Province based on the Lampung Governor Regulation No. 21/2019 concerning Spatial Utilization of Coastal Areas and Small Islands. Licensing for tourism services business with marine tourism objects includes permits for coastal waters locations and water locations. The validity period of the coastal waters management permit and the permit for the waters' location is two years, and a permit extension can be made no later than three months before the permit's validity period. Implications of licensing for the protection of coastal areas in the implementation of business licensing for tourism services in Lampung Province per the Lampung Governor Regulation No. 21/2019 have implications for protecting coastal areas around tourist objects marine tourism permit requirements must include Environmental Documents and Environmental Permits. Also, it includes a technical feasibility study document containing the coordinates of the location of use, plans for marine tourism activities, and a list of the infrastructure used.

\section{A. Book}

\section{Bibiliography}

Armida S. 2006. Pengembangan Pariwisata Daerah Memasuki Era Otonomi Daerah dan Desentralisasi. Jakarta: Universitas Indonesia.

Muladi. 2002. Demokrasi, Hak Asasi Manusia dan Reformasi Hukum di Indonesia, Jakarta: The Habibie Center.

N.M., Spelth. dan Ten Berge. 2006. Pengantar Hukum Perizinan, Jakarta: ABJM.

Pendit, Nyoman. 1994. Ilmu Pariwisata Sebuang Pengantar Perdana, Jakarta: Pradnya Paramita.

Siswanto, Heni. 2013. Rekonstruksi Sistem Penegakan Hukum Pidana Menghadapi Kejahatan Perdagangan Orang. Semarang: Penerbit Pusataka Magister.

Sumarja, F.X. 2008. Hukum Tata Guna Tanah di Indonesia. Bandar Lampung: Penerbit Universitas Lampung.

Sutedi, Andrian. 2017. Hukum Perizinan dalam Sektor Pelayanan Publik, Jakarta: Sinar Grafika.

Yuswanto, Nurmayani, Ati Yuniati, Marlia Eka Putri, Eka Deviani dan Satria Prayoga. 2014. Hukum Keuangan Negara. Lampung: Fakultas Hukum Universitas Lampung.

\section{B. Journal}

Alfonsius, Josef, and Gadi Djou. "PENGEMBANGAN 24 DESTINASI WISATA BAHARI 
KABUPATEN ENDE.” Jurnal Kawistara 3, no. 1 (April 21, 2013). https://doi.org/10.22146/kawistara.3958.

Bayi Priyono. "Perizinan Sebagai Sarana Pengendalian Penataan Ruang Dalam Perspektif Pemanfaatan Ruang Di Daerah ." Jurnal Ilmiah Administrasi Pemerintahan Daerah. Accessed January 28, 2021. http://ejournal.ipdn.ac.id/JAPD/article/view/187.

BUDI, SADAR PAKARTI. "MODEL STRATEGI PENGEMBANGAN KAWASAN PARIWISATA YANG BERDAYA SAING DAN BERKELANJUTAN : DKI JAKARTA," 2016.

Farid Budianto, Prima, Edi Susilo, Erlinda Indrayani, Fakultas Perikanan, Ilmu Kelautan, and Universitas Brawijaya. "IMPLEMENTASI PENGEMBANGAN PARIWISATA DI PULAUPULAU KECIL TERHADAP MASYARAKAT PESISIR DESA LIHUNU, KECAMATAN LIKUPANG, KABUPATEN MINAHASA UTARA, PROVINSI SULAWESI UTARA.” Jurnal ECSOFiM. Vol. 1, October 28, 2013. https://ecsofim.ub.ac.id/index.php/ecsofim/article/view/5.

Johan, Yar. "Pengembangan Wisata Bahari Dalam Pengelolaan Sumberdaya Pulau-Pulau Kecil Berbasis Ekologi: Studi Kasus Pulau Sebesi Provinsi Lampung." Jurnal Pascasarjana Institut Pertanian Bogor, 2011. http://repository.ipb.ac.id/handle/123456789/50748.

Kasus Wisata Bahari di Pulau Maratua, Studi, Didit Eko Prasetiyo, Uswatun Chasanah, Muhandis Sidqi, Budi Muhammad Ruslan, dan Suraji, Direktorat Perencanaan Ruang Laut, et al. "The Water Location Permit as the Non-Tax State Revenue (NTSR): Case Study on Marine Tourism in Maratua Island." Buletin Ilmiah Marina Sosial Ekonomi Kelautan Dan Perikanan 6, no. 1 (June 30, 2020): 37-49. https://doi.org/10.15578/marina.v6i1.8886.

Lawang, Marcella Apriani. "PENEGAKAN HUKUM TERHADAP PENCEMARAN DAN PERUSAKAN LINGKUNGAN OBJEK WISATA BERDASARKAN UNDANG-UNDANG NOMOR 10 TAHUN 2009.” LEX CRIMEN. Vol. 4, November 8, 2015. http://analisispengembanganpariwisata.blogspot.com/.

Limbong$^{1}$, Ferncius, Sugiono Soetomo ${ }^{2}$, Kata Kunci, : Taman, Nasional Karimunjawa, Dampak Perkembangan, Pariwisata Lingkungan, and Taman Nasional Karimunjawa. "Keyword: Karimunjawa National Park, Impacts of Tourism Development, The Environment Karimunjawa National Park Jurnal Ruang Volume 2 Nomor 1 Tahun.” Ruang. Vol. 2, December 24, 2014. https://ejournal3.undip.ac.id/index.php/ruang/article/view/4368.

Marasabessy, Ilham, Achmad Fahrudin, Zulhamsyah Imran, Syamsul B Agus, Program Studi, Pengelolaan Sumber Daya Pesisir, Dan Lautan, et al. "Strategi Pengelolaan Berkelanjutan Pesisir Dan Laut Pulau Nusa Manu Dan Pulau Nusa Leun Di Kabupaten Maluku Tengah Sustainable Coastal and Marine Management Strategies of Nusa Manu and Nusa Leun Islands in Central Maluku Regency." Journal of Regional and Rural Development Planning Februari 2018, no. 1: 1-22. Accessed January 28, 2021. https://doi.org/10.29244/jp2wd.2018.2.1.1-22.

Maroni, Sopian Sitepu dan Nenny Dwi Ariani. "Humanistic Law Enforcement as the Application of the Value of Justice, Expediency and Legal Certainty Based on Pancasila ." Journal of Legal, Ethical and Regulatory . Accessed January 28, 2021. https://www.abacademies.org/abstract/humanistic-law-enforcement-as-the-application-of-thevalue-of-justice-expediency-and-legal-certainty-based-on-pancasila-8551.html.

Natha, Martha Hadi, Ambo Tuwo, and Farid Samawi. "KESESUAIAN EKOWISATA SELAM DAN SNORKLING DI PULAU NUSA RA DAN NUSA DEKET BERDASARKAN POTENSI BIOFISIK PERAIRAN Suitability Ecotourism Diving and Snorkeling in Nusa Ra and Nusa Deket Island Based Biophysical Potential Water." J. Sains \& Teknologi, Desember 14, no. 3 (2014): 259-68.

Qodriyatun, Sri Nurhayati. "Implementasi Kebijakan Pengembangan Pariwisata Berkelanjutan Di Karimunjawa.” Aspirasi: Jurnal Masalah-Masalah Sosial 9, no. 2 (March 26, 2019): 240-59. https://doi.org/10.46807/aspirasi.v9i2.1110.

Ratna Sari, Yuni, and Dian Kagungan. "KEBIJAKAN PENGEMBANGAN KAWASAN WISATA BAHARI BERBASIS KEARIFAN LOKAL DAN PENGUATAN KELEMBAGAAN DESA DALAM RANGKA MENINGKATKAN KESEJAHTERAAN MASYARAKAT.” Econosains Jurnal Online Ekonomi Dan Pendidikan 14, no. 1 (March 31, 2016): 88-104. https://doi.org/10.21009/econosains.0141.07.

Sendow, Jelly N. "PERLINDUNGAN HUKUM TERHADAP KEGIATAN PENANAMAN MODAL 
$\begin{array}{lccccc}\text { PADA SEKTOR } & \text { PARIWISATA } & \text { DI } & \text { KABUPATEN MINAHASA UTARA.” } & \text { LEX } \\ \text { ADMINISTRATUM } & \text { VOL } & & 3,5015 .\end{array}$ ADMINISTRATUM. $\quad$ Vol. $\quad 3, \quad$ November

Yustinaningrum, Diah. "PENGEMBANGAN WISATA BAHARI DI TAMAN WISATA PERAIRAN PULAU PIEH DAN LAUT SEKITARNYA MARINE TOURISM DEVELOPMENT IN PARK TOURISM ISLANDS OF PIEH AND SEA SURROUNDING.” Agrika. Vol. 11, May 1, 2017. https://doi.org/10.31328/JA.V11I1.455. 
